\title{
BRYOPHYTE FLORA OF HELAN MOUNTAIN IN CHINA
}

\author{
БРИОФЛОРА ГОРЫ ХЕЛАН, КИТАЙ \\ DOng-Ping ZHAO ${ }^{1}$, XUE-Liang BAI ${ }^{1}$, XiAn-DAO WANG ${ }^{1}$, Hui-Min Jing ${ }^{1}$ \\ ДОНГ-ПИНГ ЖЧАО, ХУ-ЛИАНГ БАЙ, СИАНЬ-ДАО ВАНГ, ХУ-МИН ЖИНГ
}

Abstract

\begin{abstract}
The bryophyte flora of Helan Mountain (China, Inner Mongolia Province) is studied and analyzed. It includes 201 taxa (10 Hepaticae and 191 Musci, including subspecies and varieties) from 77 genera and 30 families. Most of species have a broad North Temperate distribution. With the increase of altitudes and the variation of habitats, the distribution of bryophytes on Helan Mt. shows a clear vertical zonation. Based on our observation, we have classified the zonation of bryophytes in Helan Mountain into 5 altitudinal belts.
\end{abstract}

Резюме

Изучена и проанализирована бриофлора горы Хелан (Китай, провинция Внутренняя Монголия). Она включает 201 таксон (10 печеночников и 191 мох, в том числе несколько подвидов и разновидностей) из 77 родов и 30 семейств. Большинство видов имеет широкое распространение в умеренной зоне Северного полушария. По мере повышения абсолютной высоты на горе Хелан возрастает разнообразие местообитаний, формирующее выраженную вертикальную поясность; по мохообразным можно выделить до пяти поясов.

INTRODUCTION

Helan Mountain is situated at the provincial border between Inner Mongolia and Ningxia of China. The study of bryophytes of Helan Mountain started in the $60 \mathrm{~s}$, from 1962 to 1965 . Tong (1963) made the first bryophytes collections in the western slope of Helan Mountain and compiled a moss list based on the specimens. Since then, other bryologists, such as, Bai, Gao, and Lu, have collected bryophytes in western and eastern slope of the mountain. Lu (1998) identified 29 taxa of frequent bryophytes in the eastern slope. Bai carried out long-term bryological works in this area in 1987-1998 and, together with other authors, reported 2 genera and 14 species from Helan Mountain as new to China, by then, 164 mosses were known from the western slopes. In 2000, Bai and Tan described a new species Tayloria rudimenta X.-L. Bai \& B.C. Tan (Musci, Splachnaceae) collected in Suyukou.

Still, as a whole, the reports of bryophytes from Helan Mountain have been rather scattered and incomplete, due especially to a lack of specimens collected from and the systematic study of the bry- oflora on the eastern slope. Thus, the development of a list of bryophytes found in this area is particularly needed. In order to complete the study of bryophyte flora and species diversity, we conducted a field survey of the bryophyte diversity from the eastern slope of Helan Mountain between 2003 and 2004. The collection localities are shown in Fig. 1

\section{STUDY AREA}

Helan Mountain is located at $33^{\circ} 07^{\prime}-39^{\circ} 30^{\prime}$ $\mathrm{N}, 105^{\circ} 20^{\prime}-106^{\circ} 45^{\prime} \mathrm{E}$. The highest peak is known as "Obogda", up to $3556 \mathrm{~m}$ above sea level. Helan Mountain occupies an area of 6000 sq. km, and extends about $250 \mathrm{~km}$ from north to south and about $20-40 \mathrm{~km}$ east to west. Its general altitude ranges from 2000 to $3000 \mathrm{~m}$ and the relative elevations are from 1500-2000 $\mathrm{m}$ (Shi et al., 1989).

\section{Climate}

The climate of the study area is typically continental one, with four distinct seasons. Although the area is dry with little precipitation, the acute exchanges of cold and warm air masses at high elevations produce a mountain climate in the study area. Based on the data provided by the meteorological stations, Tian (1996) reported that the av-

1 - Dept. of Biology, Inner Mongolia University, Hohhot 010021, China. 


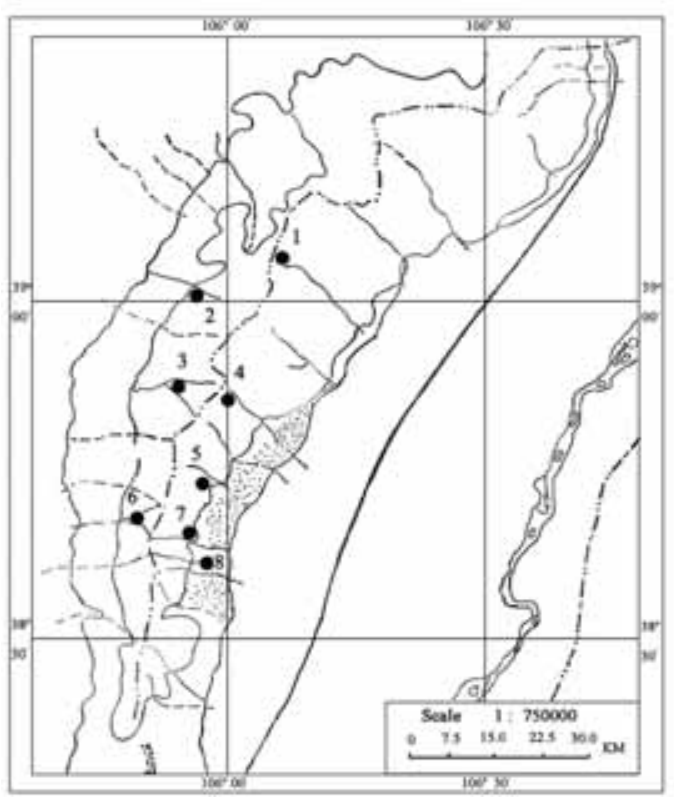

erage local annual temperature decreased from $+8.5^{\circ} \mathrm{C}$ at the base of mountain to $-0.8^{\circ} \mathrm{C}$ in alpine zone, and the temperature dropped $0.62^{\circ}$ at every increase of $100 \mathrm{~m}$ of the elevation. The precipitation, reportedly, occurred mainly between July and September and the mean annual precipitation is between $183.3 \mathrm{~mm}$ (Shizuishan) and 202.8 $\mathrm{mm}$ (Yinchuan); vertical differences are also seen: the amount of precipitation is increasing by 13.2 $\mathrm{mm}$ at every increase of $100 \mathrm{~m}$.

\section{VEGETATION}

Helan Mountain forms an important boundary of climatic pattern and vegetation in northwest China: the eastern slope of Helan Mountain belongs to the steppe climate with steppe vegetation, while the western slopes are characterized by having a desert climate, and a desert vegetation. There is also a strong differentiation of vegetation on sunny and shady slopes. In the steppe belt on low hillsides, steppe communities inhabit the sunny slopes but mesophilous shrubs occur on shaded slopes (Liang \& al., 2004). In the coniferous forest belt at the mid-elevation zone, the community of Picea crassifolia are distributed widely on shaded slopes, but open forests of $U l$ mus glaucescens and Juniperus rigida, and other mesophilous shrubs occur on the sunny slopes. At $3000 \mathrm{~m}$ and upwards, the vegetations of sunny and shady slopes become similar.
Fig. 1. The collecting localities of bryophytes in Helan Mountain: 1-Rujigou (RJ), 2-Beisi (BS), 3-Halawugou (HL), 4-Shaguozhou (SG), 5-Suyukou (SY), 6-Nansi (NS), 7-Huangqikou (HQ), 8-Xiaokouzi (XK).

\section{GEOLOGY AND SOILS}

The study territory has a complicated geological structure. The most widespread bedrocks are limestones, gneisses, sandstones and shales and quartzites (Di, 1986). From our own field observation, channels and banks of streams are often not rocky. However, boulders occur everywhere on slopes of the mountains, and large rocky outcrops are located mainly in the river valleys, on mountain peaks and on abruptly vertical cliffs.

The types of soil in the study area are the mountain meadow soil, mountain sierozem soil and mountain grey cinnamon soil (Xie \& al., 1999).

\section{STUDIES OF VERTICAL DIFFERENTIATION OF}

\section{BRYOPHYTE DISTRIBUTION}

Except on the eastern slope, Helan Mountain is surrounded by the desert at the western, northern and southern side. The desert landscape is seen at the forefront, reaching about $1500 \mathrm{~m}$ alt. In this habitat, the surface is bestrewed with rock debris and a lot of small plants occur in rock crevices or on coarse rocky efflorescence. The desert vegetation is mainly composed of gobi and tethyan floral elements, such as Reaumuria soongorica, Salsola passerina, Stipa breviflora, Stipa glareosa, etc., according to a report prepared by the Inner Mongolia-Ningxia complex expert team of the Chinese Academy of Sciences (1985).

Only a few of bryophytes have been found on soil in the flat desert, however, a small low rocky outcrop within a flat area will allow the growth of some mosses. We were able to find 31 species in such a habitat. The most common mosses in these xeric habitats are: Didymodon vinealis, Hypnum cupressiforme, Bryum argenteum, Syntrichia sinensis, Crossidium squamiferum, Aloina rigida and Grimmia laevigata.

Since Helan Mountain is the highest range in Inner Mongolia with a relatively high elevations of about $2100 \mathrm{~m}$ (Tian, 1996), the local vegetation shows clearly vertical zonations that are quite similar between the eastern slopes and the western slopes (Tian, 1996; Liang et al., 2004). 
The distribution of bryophytes is closely correlated with the distribution of tracheophytes in each of the corresponding zones.

We investigated the changes of bryophyte zonation in a, vegetatively speaking, typical area starting from a valley near "Obogda" to the alpine zone at Suyukou. Based on the field data of elevation, local climate, relative humidity, and the characterization of the major communities of tracheophytes and bryophytes, we have formulated the following five vertical zonations of bryophyte distribution on Helan Mountain.

(1) At lower elevations, below $1900 \mathrm{~m}$, the climate is relative warm and arid, and soil type is mainly mountain sierozem soil. The Mongolia steppe communities inhabit the sunny slope, but mesophilous shrubs occur on shaded slopes. The more widespread species here are the xeric mosses, like Didymodon vinealis, Syntrichia sinensis, Grimmia laevigata, Aloina rigida, etc.

(2) Between 1900-2200 m, the temperature dropped a little. Soil type is the common mountain grey cinnamon soil, and the soil layer is rather thick. In this zone, stands of Pinus tabulaeformis, with the relative humidity under the forest canopy varying from $65 \%$ to $70 \%$, cover most parts of the area forming the principal plant resource. The bryophytes are in an inferior position in local niche competition; still, altogether, we collected 55 species in this belt. The mosses were found mostly growing on soil and rocks in ravines, slopes, canyons and on brook banks. They are: Abietinella abietina, Amblystegium serpens, Brachythecium albicans, Bryoerythrophyllum brachystegium, B. gymnostomum, B. recurvirostre, Didymodon rigidulus var. flexicuspis, D. rigidulus var. icmadohilus, D. tophaceus, D. vinealis, Encalypta alpina, Fissidens bryoides, Gymnostomum calcareum, Hymenostylium recurvirostrum, Hypnum cupressiforme, $H$. hamulosum, $H$. pallescens, $H$. vaucheri, Timmia bavarica, Timmiella anomala, etc. The dominant moss taxa of the colonizing synusia are Hypnum, Brachytheci$u m$ and Didymodon.

(3) From elevations $2200 \mathrm{~m}$ to $2350 \mathrm{~m}$, mixed forests consisting of Picea crassifolia and Populus davidiana dominate the zone. The soil type is mountain leach grey cinnamon soil, and the relative humidity is $75 \%-81 \%$. This elevational zone is relatively rich in bryophytes. Here we recorded 92 species. The local moss flora is composed of many petrophytic mosses: Abietinella abietina, Brachythecium albicans, B. kuroishicum, B. salebrosum, Cirriphyllum piliferum, Ditrichum flexicaule, Hypnum cupressiforme, Timmia bavarica, Trachycystis ussuriensis. The dominant taxa of the colonizing synusia are Abietinella, Brachythecium, Timmia, Cirriphyllum, Trachycystis and Ditrichum.

(4) The elevation range, 2360-2900 m, supports a constructive plant communities - Picea crassifolia forest. The type of soil covering this belt is the mountain leach grey cinnamon soil. The forest floor is shaded and damp with a relative humidity of $78 \%-87 \%$. Here the vascular plants are rather sparse while mosses grow well. In many places, the forest floor is entirely covered with bryophytes, with coverage reaching $82.52 \%$. Altogether we collected 99 species of bryophytes, with the mesophytes and petrophytes in dominant position. The mosses composed of about 11 species: Abietinella abietina, Distichium capillaceum, Ditrichum flexicaule, Hypnum bambergeri, $H$. cupressiforme, $H$. fertile, $H$. pallescens, Mnium heterophyllum, $M$. laevinerve, M. thomsonii and Pseudostereodon procerrimus. The dominant species of colonizing synusia are Abietinella, Distichium, Ditrichum, Hypnum and Pseudostereodon.

(5) From $2900 \mathrm{~m}$ to the summit is the uppermost zone of the mountain where the temperature is cold and the precipitation is abundant. The soil type is of mountain meadow soil. The relative humidity varies greatly between $45 \%$ and $75 \%$. The habitat is too hostile to allow for the growth of trees. Several alpine shrubs known from the alpine meadow zone are represented here, such as Caragana jubata, Salix cupularis var. lasiogyne and some Artemisia (Xie et al., 1999). Here we found 64 species of mosses and the most common communities belong to the petrophytes and geophytes. Interestingly, the mosses often occur here randomly in small, isolated spots. The dominant taxa of moss communities are Hypnum, Didymodon and Grimmia. The most common species are Didymodon rufidulus, D. giganteus, Grimmia subanodon, Jaffueliobryum wrightii and Voitia nivalis.

The species composition and zonal distribu- 
tion of mosses on the eastern slope is similar to that seen on the western slope. For examples, at foothill, one sees the same Pterygoneurum subsessile, Aloina rigida, Didymodon vinealis, etc. In the Pinus tabulaeformis forest, the presence of Hypnum cupressiforme, $H$. vaucheri, Brachythecium albicans. In Picea crassifolia forest are common as Pseudostereodon procerrimus, Abietinella abietina, Ditrichum flexicaule, Distichium capillaceum, etc, are common. The main reason for this similarity is that both eastern slope and western slope have the same prevailing climate and vegetational zones, for instance. Both the two slopes possess abundant in forests dominated by Pinus tabulaeformis, Picea crassifolia, and mixed forest, as well as alpine meadows.

\section{ANALYSIS OF THE CHARACTERISTICS OF SPECIES COMPOSITION}

In total, the bryophyte flora of the area includes 201 taxa (including subspecies and varieties) belonging to 77 genera and 30 families, including 10 species of Hepaticae and 191species of Musci. The number is rather high not only in families and genera, but also in species. Obviously, the main diversity is confined to the forests or to areas sheltered by mountain, like deep canyons and inner portions of mountain massif.

Helan Mountain is located at inland of China and the climate is relatively cold and xeric. Due to the xeric climate, the species of hepatics are generally rare. The xeric environment of the study area can be characterized by its species composition of the flora:

(1) In the present checklist of bryophytes of Helan Mountain, 66 species of Pottiaceae are listed. The family is abundant both in the number of genera and species of xeric mosses, such as Aloina brevirostris, Tortula atrovirens, Syntrichia pagorum, Crossidium squamiferum, Pterygoneurum subsessile, Microbryum starckeanum. Members of Pottiaceae occur in the woodland, in forests in open areas, along border of forests and in alpine meadows, on rock outcrops and soils.

Grimmiaceae include 12 species. Most species of this family are cosmopolitan and also have broad distribution in the subtropical and temperate zones. Helan Mountain is located in North temperate zone and the climate is relatively xeric what it is very suitable for the growth of Grimmiaceae.
For example, Grimmia ovalis and Grimmia laevigata have wide distribution in the study area; in Helan Mountain Indusiella thianschanica and Jaffueliobryum wrightii which were known from Tibet and Xinjiang are found in abundance. In addition, we also collected Coscinodon cribrosus that was reported previously only from Taiwan and Qinling Mt. in mainland China.

(2) Bryaceae is quite rich in species diversity: 19 species were identified; members of this family, as well as it is represented worldwide, have extensive ecological amplitude and are adapted to various habitats. In Helan Mountain most species are found in xeric environment, springy or swampy area, and forest floor.

A total of 17 species of the family Hypnaceae were collected in this area, and the most common species are also the Cosmopolitan, North temperate and East Asia elements. Members of this family are among the dominant components of moss cover in forests, e.g. Eurohypnum leptothallum, Hypnum bambergeri, $H$. cupressiforme, $H$. vaucheri, Podperaea krylovii, Pseudostereodon procerrimus.

In the study area, the family Mniaceae consists of 13 species. The family is known from many countries around the world, and its general distribution obviously seems to center more or less in temperate territories. Members of Mniaceae can be found on soil, rotten logs and wet rocks in forest and springy or swampy sites in the study area.

(3) Only 11 taxa of the family Amblystegiaceae were found in the area. Most species are hydrophytic mosses, and are adapted to very wet conditions ecologically. One can see that the presence of Amblystegiaceae reflects that the environment of Helan Mt. is characteristic of complicated and diverse landform.

In conclusion, the pattern of moss diversity as a whole, and in Helan Mt. in particular is obviously correlated with the availability of water. Because of the xeric environment, the xerophytic mosses, such as Pottiaceae and Grimmiaceae, are in dominant position.

\section{FLORISTIC ELEMENTS}

Bryophytes of Helan Mountain can be divided into different floristic elements based on their ranges. The names given to each of the floristic elements of bryophytes are different when enu- 
merated and used by different authors. In this paper, we adopt the categorical names based on the distribution of carpophyte of China as documented by Wu (1983)

(1) Most species of bryophytes in the study area, about 105 species, have wide North Temperate distribution and they are quite common also in other parts of Inner Mongolia (e.g. Abietinella abietina, Brachythecium plumosum, Cephaloziella rubella, Distichium capillaceum, Ditrichum flexicaule, Entodon concinnus, Jamesoniella autumnalis, Hypnum vaucheri, Pseudostereodon procerrimus, Syntrichia princeps, Timmia bavarica, etc.).

(2) East Asia and North American elements. These are species occurring in temperate East Asia and North America. Examples are Grimmia pilifera, Orthotrichum sordidum and Anomodon minor $(\mathrm{Wu}$ $\&$ al., 2001). The species of East Asian element have their distribution within the temperate and warm temperate zones in China, Japan and Korea. Some of them extend their range to the Himalayas. This element includes three sub-elements:

(a) Sino-Himalaya element. These bryophytes occur only in the Himalayas and in the Chinese provinces of Yunnan and Sichuan, e.g. Anoectangium thomsonii, Bryoerythrophyllum gymnostomum, Hymenostylium recuvirostrum var. cylindricum, etc.

(b) Sino-Japanese element. They are bryophytes occurring in Japan and central China, but absent in the Himalayan region. e.g., Bryoerythrophyllum brachystegium, Hymenostylium recuvirostrum var. insigne, Hypnum vaucheri $\mathrm{f}$. tereticaulis, Okamuraea brachydictyon, Plagiomnium maximoviczii, etc.

(c) Japan-Sino-Himalaya element. They are bryophytes occurring in Japan and the Himalayas, e.g. Anoectangium aestivum, Brachythecium buchananii, Didymodon rigidulus var. flexicuspis, Entodon caliginosus, etc.

(3) Endemic elements contain taxa which appear to be endemic in smaller areas, such as:

(a) Endemic to China. This element contains 7 species: Aloina obliquifolia, Didymodon rufidulus, Molendoa sendtneriana var. yunnanensis, Weissia edentula, Weissia semipallida, etc.

(b) Endemic to Mongolia Plateau. Only one species: Syntrichia bidentata. (c) Endemic to Helan Mountains. Examples are Cratoneuron longicostatum and Tayloria rudimenta.

\section{NEW RECORDS FOR THE BRYOPHYTE FLORA OF CHINA}

The results of our survey brought the following addition of three new moss records for China. The description of the species is based on Chinese specimen(s) collected.

Microbryum starckeanum (Hedw.) Zand., Gen. Pottiaceae: Moss. Harsh. Envir., Bull. Buffalo Soc. Nat. Sci. vol. 32: 240. 1993. Pottia starckeana (Hedw.) C. Müll., Syn. Musc., 1849; Moss Flora Brit. Irel. 235. 1978. Weissia starckeana Hedw., Spec. Musc. 65, 1801. - Fig.2.

Plants small, crowded, forming a low tufts, green above, reddish brown below. Stems very short. Leaves oblong-lanceolate or very broadly ovate, acute, 0.7-1.2 mm long; margins strongly recurved, entire, marginal cells less papillose and somewhat thicker walled than medial; costa reddish, excurrent in a cuspidate point, costa cells papillose; cells above small, 10-16 $\mu \mathrm{m}$ wide, round-quadrate to hexagonal, densely papillose; basal cells rectangular, ca. 23-49 $\mu \mathrm{m}$ long, 10-15 $\mu \mathrm{m}$ wide, with thin walls. Paroicous. Setae erect, ca. $2.7 \mathrm{~mm}$ long; capsule ellipsoid, ca. $0.5 \mathrm{~mm}$, dark brown, not widemouthed; Operculum short conical; calyptra cucullate; annulus absent; peristome absent or rudimentary. Spores about 16-21 $\mu \mathrm{m}$, light brown, obtusely tuberculate.

Distribution: Central, West and south Europe, Canaries, Madeira, Algeria, Syria, Western part of America, Australia.

Habitat: In Helan Mountain it was found On soil in Pinus tabulaeformis + Junpierus rigida forest.

Chinese specimens examined: Helan Mountain: SY029, RJ340, alt.: $2300 \mathrm{~m}$.

Operculum of Microbryum starckeanum (Fig. 2-1) was drawn from dry plants. Strongly recurved leaf margins may be the result of xeric environment of Helan Mt.

Hypnum bambergeri Schimp., Syn. Musc. Eur., 698, 1860.- Fig. 3.

Plants medium-sized, in green or yellow-green cushions. Stems prostrate to ascending, to $3-8 \mathrm{~cm}$ long, with weak central strand, irregularly to subpinnately branched. Pseudoparaphyllia broadly 

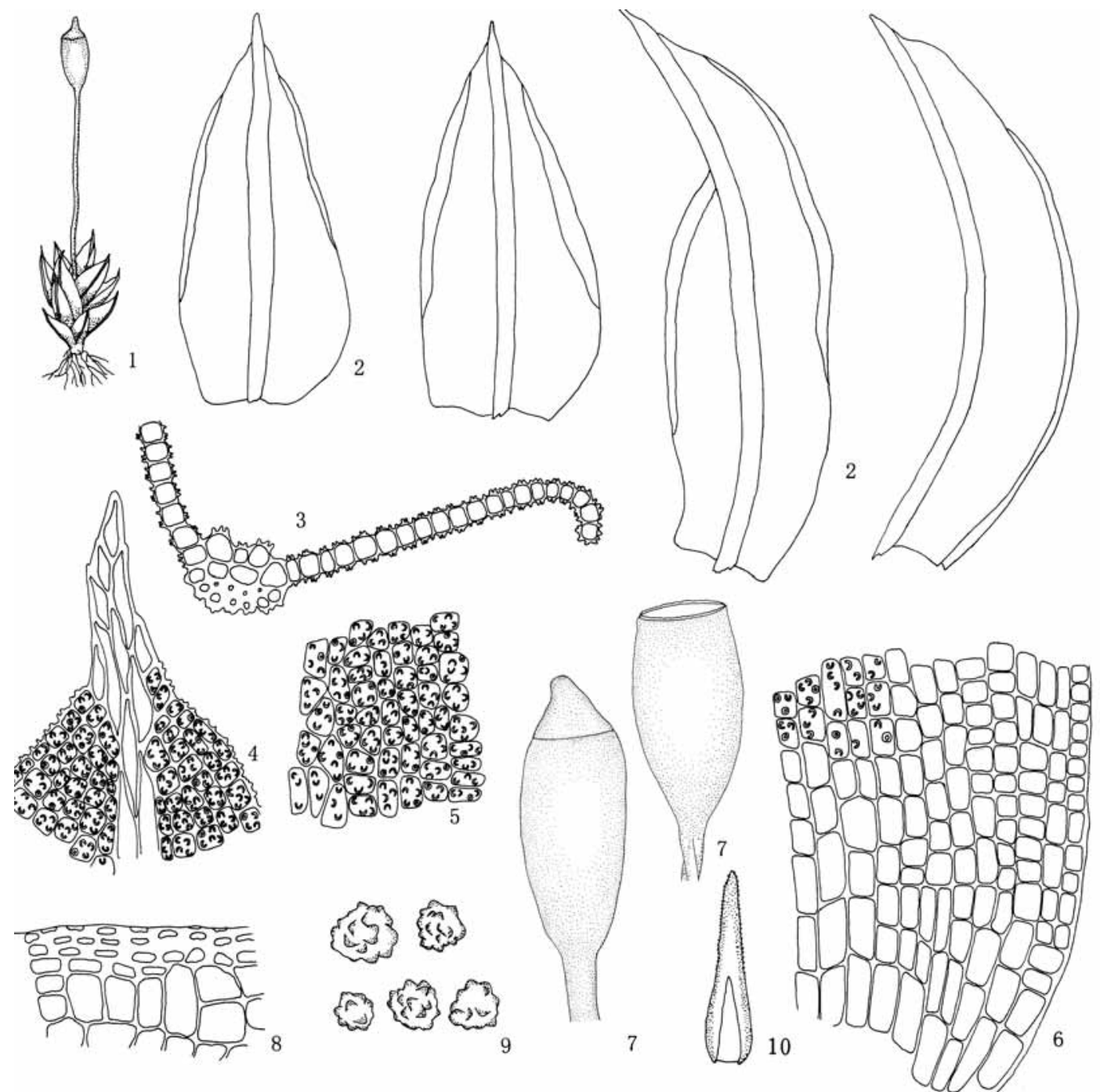

Fig.2. Microbryum starckeanum (Hedw.) Zand. 1: Plant with sporophyte $(\times 7.9)$; 2: leaves $(\times 68)$; 3: Cross section of costa and portion of leaf $(\times 284)$; 4: apical leaf cells $(\times 284)$; 5: median leaf cells $(\times 284)$; 6: basal marginal leaf cells $(\times 284)$; 7: capsules with operculum $(\times 26)$; 8: cells at mouth of capsule $(\times 284)$; 9 : spores (×284); 10: calyptra $(\times 26)$.

ovate. Stem and branch leaves similar, crowded, falcate to circinate-secund, 1.9-2.4 mm long; margins plane, entire; costa double, yellow, very slender; upper leaf cells $28-49 \mu \mathrm{m}$ long; median leaf cells 41-62 $\mu \mathrm{m}$ long; alar cells subquadrate to rectangular, thick-walled. Dioicous. Sporophytes not seen in Helan Mountain.

Distribution: Hypnum bambergeri has an arctic-alpine distribution in Europe and occurs in Azores and Siberia, in North America from British Columbia in the west to Newfoundland and
Quebec in the east. The species is widespread across the Arctic region.

Habitat: In Helan Mountain it was found on soil in Picea crassifolia forest and alpine meadows.

Chinese specimens examined: Helan Mountain: SY380, Alt.: 2500 m; SG113, alt.: 3400 m.

Bryum elegans Nees ex Brid., Bryol. Univ. 1: 849. 1827; Arctoa. 9: 212. 2000.—Fig. 4.

Plants in dense, soft green tufts. Stem reddish, straight, $0.5-1.5 \mathrm{~cm}$ long. Upper leaves closely imbricate, appressed, sometimes loosely 

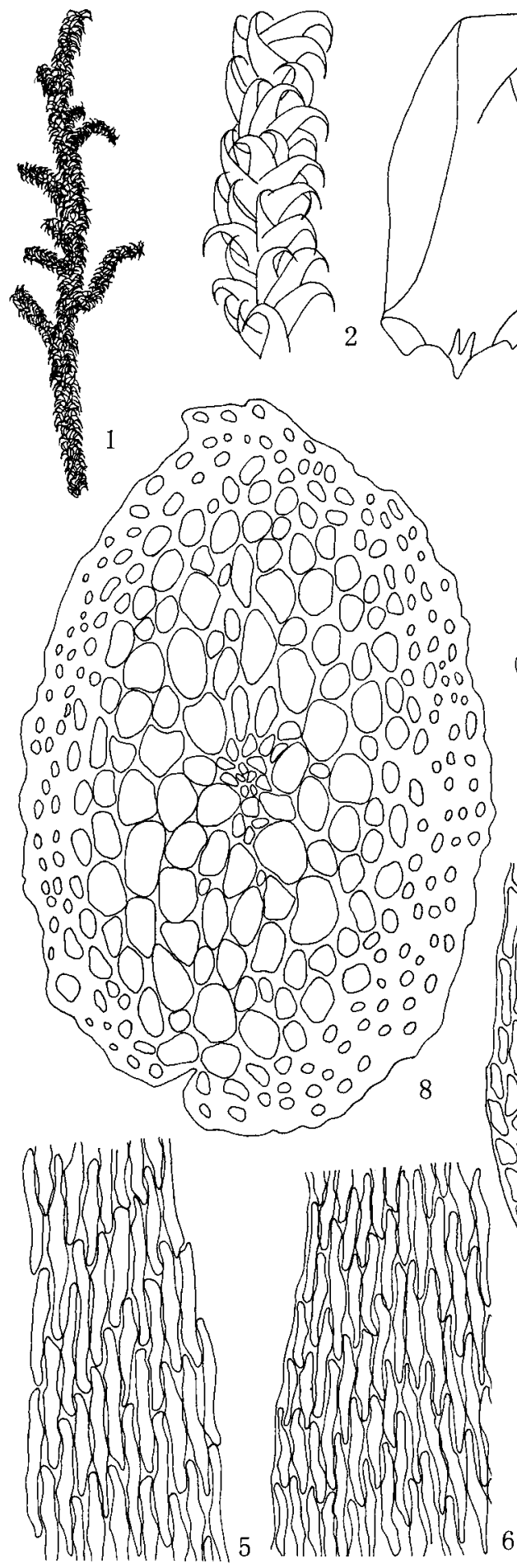

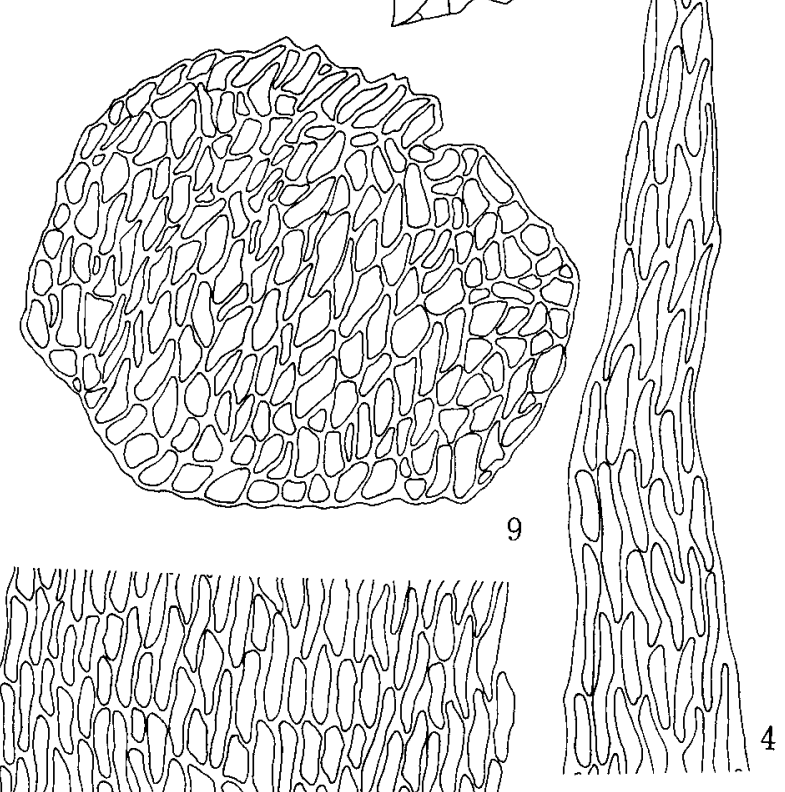
on 0 ono Dou 00 , on

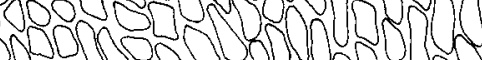

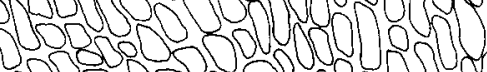

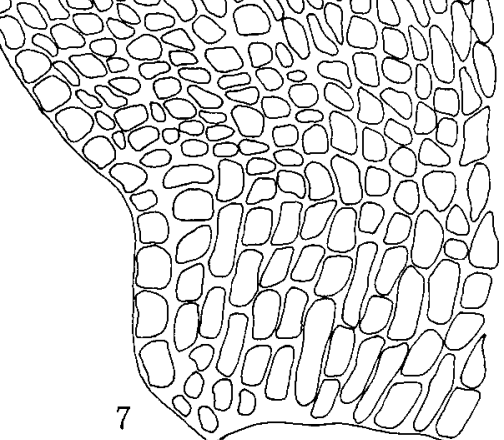

Fig.3 Hypnum bambergeri Schimp.

1: Plant $(\times 6.3)$; 2 : shoot $(\times 25)$; 3: leaves $(\times 31.5)$; 4 : apical leaf cells $(\times 340)$; 5: median leaf cells $(\times 340) ; 6$ : median marginal leaf cells $(\times 340)$; 7 : basal leaf cells $(\times 340) ; 8$ : cross section of stem $(\times 340)$; 9: pseudoparaphyllium $(\times 340)$. twisted when dry, concave, broadly ovate, not decurrent, 1.1-1.9 mm long, 0.6-1.0 mm wide, lower leaves less smaller; margin plane, entire, narrowly recurved at base; border distinct, 1-2 rowed, composed of somewhat longer and narrower cells; costa strong, tapered in upper leaf 

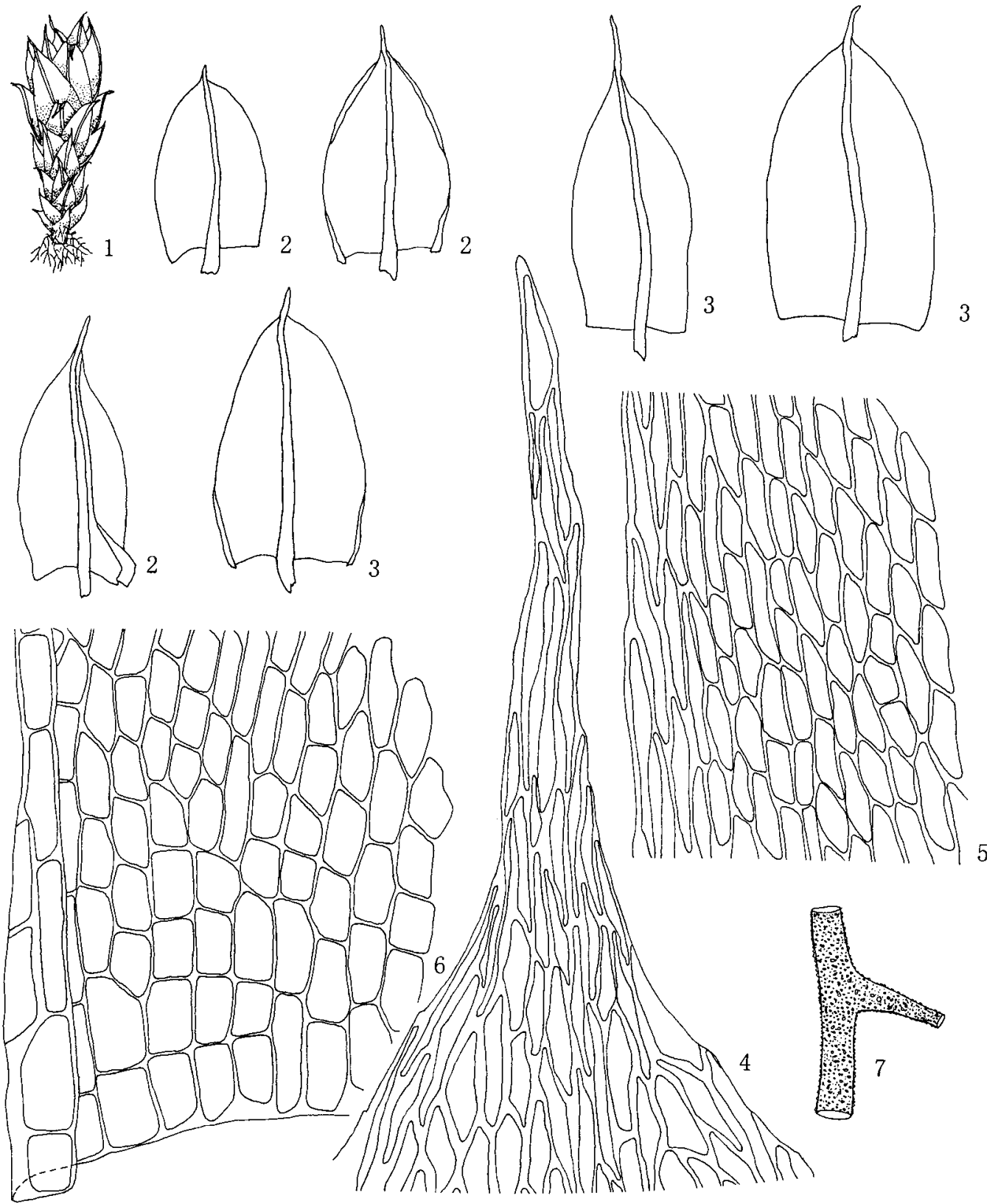

Fig.4. Bryum elegans Nees ex Brid. 1: Plant $(\times 12.6)$; 2: perigonial leaves $(\times 31.5)$; 3: perichaetial leaves $(\times 31.5)$; 4: apical leaf cells $(\times 340)$; 5 : median marginal leaf cells $(\times 340) ; 6$ : basal marginal leaf cells $(\times 340) ; 7$ : rhizoid $(\times 340)$.

and ending below acumen, or strongly excurrent in mucronate to piliferous point; upper cells regular or irregular rhombic; basal cells oblong to rectangular, thin-walled, 36-62 x 15-26 $\mu \mathrm{m}$. Perichaetial leaves lanceolate, margin plane, costa percurrent. Rhizoids brown to reddish-brown, very coarsely papillose. Axillary filaments lack- ing. Sporophytes not found in the study area.

Distribution: Northern and montane parts of Europe, Middle European Russia, Iceland.

Habitat: On soil in alpine meadows.

Chinese specimens examined: Helan Mountain: SG82, alt.: $3400 \mathrm{~m}$. 

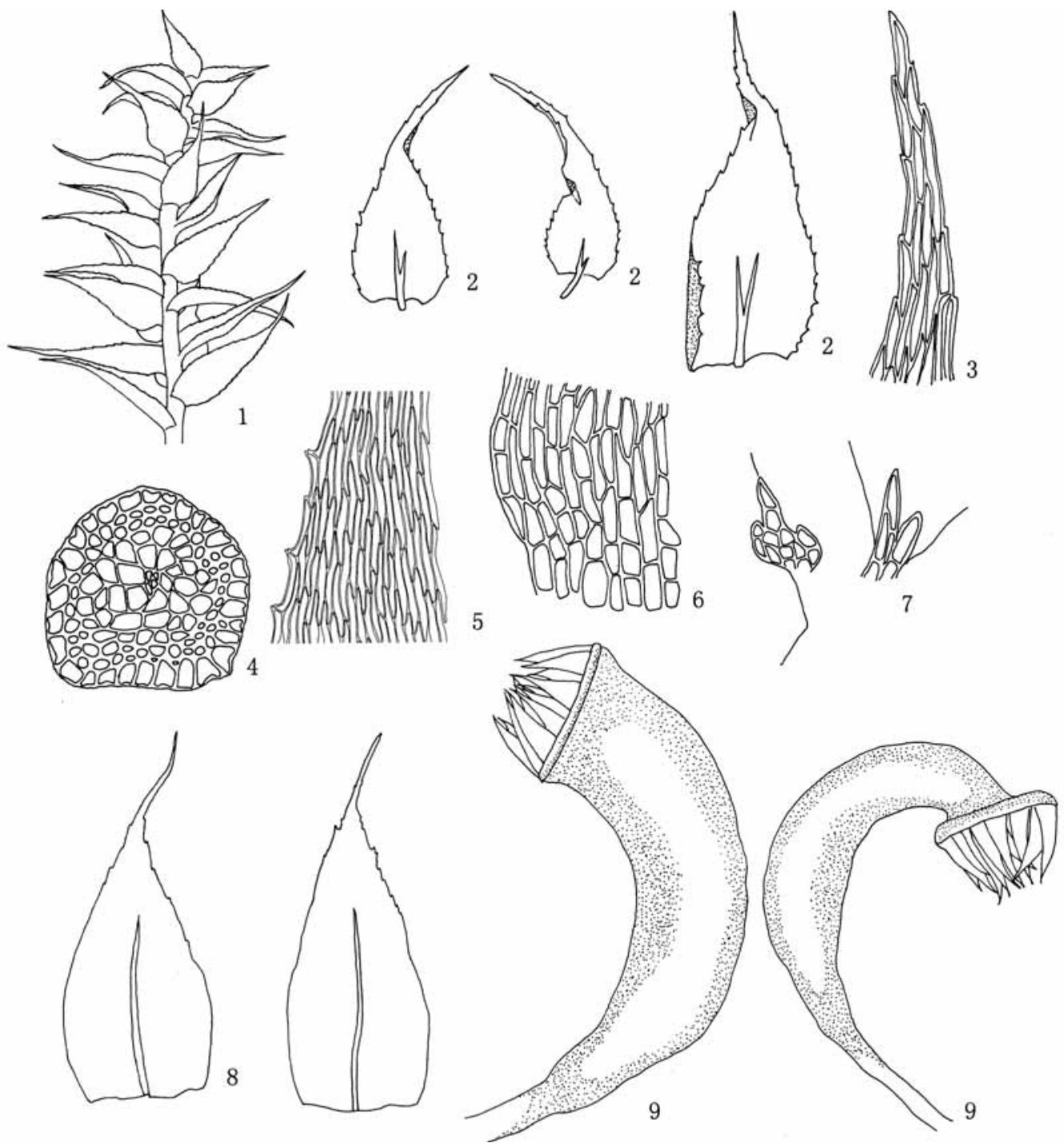

Fig.5. Podperaea krylovii (Podp.) Iwats. \& Glime 1: Portion of plant $(\times 29.5)$; 2: leaves $(\times 59)$; 3: apical leaf cells $(\times 236)$; 4: cross section of stem $(\times 236)$; 5 : median marginal leaf cells $(\times 236)$; 6: basal marginal leaf cells $(\times 236)$; 7 : pseudoparaphyllia $(\times 236)$; 8: perichaetial leaves $(\times 29.5)$; 9: capsules, showing when moist and dry $(\times 29.5)$.

\section{SECOND RECORD FOR CHINA}

Ignatov et al. (1996) reported Podperaea krylovii as a new record for China, but very briefly and without any description and illustration of Chinese plants, so they are here as follow:

Podperaea krylovii (Podp.) Iwats. \& Glime, J. Hattori Bot. Lab. 55: 495. 1984. Chrysohypnum krylovii Podp., Spisy Prir. Fak Masarykovy Univ. 116, t. 28, f. 'krylovi'. 1929. — Fig. 5

Plants in small, loose green mats. Stem prostrate, ca. $1 \mathrm{~cm}$ long, without central strand, irreg- ularly branched. Pseudoparaphyllia ovate to lanceolate. Leaves lanceolate, gradually acuminate, 0.4-0.7 mm long, serrate all around, the teeth near the base double-celled; costa double or forked, short and weak; basal cells oblong or rectangular, 14-28 x 7- $15 \mu \mathrm{m}$. Autoicous. Perichactial leaves $1.4 \times 0.6 \mathrm{~mm}$, serrulate, smooth, costa reaching above mid-leaf. Capsules ca. $1 \mathrm{~mm}$ long, arcuate and strongly contracted below the mouth when dry; operculum conic; annulus not differentiated; peristome double. 
Distribution: South Siberia (westward to Altai), Russian Far East, northern Japan (Hokkaido) and north-eastern China.

Habitat: On soil at rock bases in Pinus tabulaeformis + Picea crassifolia + Populus davidiana and Juniperus rigida forest.

Chinese specimens examined: Helan Mountain: HQ269, alt.: $1900 \mathrm{~m}$.

Podperaea krylovii was collected not only in Helan Mt. but also in Ordos and the northern Yanshan of Inner Mongolia.

\section{UPDATED LIST OF SPECIES COLLECTED FROM HELAN MOUNTAIN}

(Note: '**' indicates a new record species to China, and '*' new to Helan Mountain)

\section{LIST OF HEPATICAE}

* Cephaloziella rubella (Nees) Warnst. [2000-2500 m/ SY057-058, SY075, SY088, SY124, SY131-132, SY136, SY152-153, SY160, SY180] - On soil in Pinus tabulaeformis + Picea crassifolia + Populus davidiana and Ulmus glaucescens forest.

* Jamesoniella autumnalis (DC.) Steph. [2500 m/ BS1279J] On soil in Picea crassifolia forest.

* Mannia fragrans (Balbis.) Fry et Clark [2500-3000 $\mathrm{m} / \mathrm{SY} 024, \mathrm{XK} 212$, XK221, XK245] - On soil at rock bases, in Picea crassifolia forest.

* M. triandra (Scop.) Grolle [2000-2500 m/XK216218, XK250-251, NS2173, SY88] - On dry rocks on cliff in alpine zone, on soil in Picea crassifolia forest.

Marchantia polymorpha L. [2600 m/HL1364] - On wet rock outcrops along creeks in Picea crassifolia forest.

* Plagiochasma rupestre (Forst.) Steph. [2000-2500 m/XK196, XK204, XK213] - On soil under shady rocks, in rock crevices.

Plagiochila ovalifolia Mitten [2500m-3400 m/SG98, HL1331, HL1344, as $P$. asplenioides] - On soil in Picea crassifolia forest at creek bank, on soil in alpine meadows.

* Reboulia hemisphaerica (L.) Raddi [2300 m/XK196] - On soil under shaded rocks.

* Riccia sorocarpa Bisch. [2200-2350 m/XK214, XK226] - On wet soil at rock bottom.

Scapania cuspiduligera (Nees) K.Mьll. [2600-3000 m/ SY025, HL2007] - On soil in Picea crassifolia forest, on rocks in alpine meadow.

\section{LIST OF MOSSES}

Abietinella abietina (Hedw.) Fleisch. (= Thuidium abientinum (Hedw.) Turn.) [2100-2700 m/SY023, SY055, HQ293, RJ366, BS1215, HL1867, NS2113] - It is the dominant species of moss cover in Picea crassifolia forest and Picea crassifolia + Populus davidiana forest.

* Aloina brevirostris (Hook. \& Grev.) Kindb. [2200 m/ SY114] - On soil on sunny slopes with numerous rocky outcrops.

A. obliquifolia (C.Müll.) Broth. [1900-2400 m/SY001, SY182-183, HL1848, NS2127] - On soil on slopes, on the top of old walls; on soil in relatively mesic habitats (close to creeks), often found on soil in forest.

A. rigida (Hedw.) Limpr. [1560-2500 m/SY006, SY072, SY108, XK240, RJ305, BS1156, HL2061, NS2122, HL1835] - On soil on old walls.

Amblystegium riparium (Hedw.) B.S.G. (= Leptodictyum riparium Hedw.) [2600-2800 m/HQ279, BS1288] - On wet soil in the valley with temporary creek.

A. serpens (Hedw.) B.S.G. [2000-2900 m/SY010, SY044, SY159-160, SY171, XK197-198, BS1252, HL2063] - On damp soil and wet shaded rocks in Picea crassifolia and Pinus tabulaeformis forest.

A. serpens var. juratzkanum (Schimp.) Rau \& Herv. [2700 m/BS1298] - On wet soil.

A. tenax (Hedw.) C.Jens. var. spinifolium (Schimp.) Crum \& Anderson (= Hygroamblystegium tenax var. spinifolium (Schimp.) Jenn.) [2300 m/BS1173] - On wet rocks in creek in springy area.

* Anoectangium aestivum (Hedw.) Mitt. [2000-2400m /SY032, SY070, SY075, SY137] - On soil on shady rock faces in Pinus tabulaeformis + Picea crassifolia + Populus davidiana and Ulmus glaucescens forest; on wet soil in creek valleys.

A. thomsonii Mitt. [2000-2400 m/SY039, SY070, SY148, XK191, XK201, BS1220] - On soil on shady rock faces in Pinus tabulaeformis + Picea crassifolia + Populus davidiana and Ulmus glaucescens forest.

* Anomobryum filiforme (Dicks.) Husn. [1800 m/ XK200] - On soil in spring area; on wet to mesic soil at creek bank.

Anomodon minor (Hedw.) Fuernr. [2300 m/XK247] On soil at rocks bases.

Barbula indica (Hook.) Spreng. in Steud. (= Semibarbula indica (Hook.) Herz. ex Hilp.) [3000-3200 m/ HL1953, HL1324] - On soil on rock faces; on shaded ground under the canopy of shrubs in mountain steppe. 
* B. unguiculata Hedw. [2000-2700 m/SY030, SY088, SY125-126, SY165, XK242, SY98] - On soil under open rocks in Pinus tabulaeformis + Picea crassifolia + Populus davidiana and Ulmus glaucescens forest.

Brachythecium albicans (Hedw.) B.S.G. [1800-2700 m/SY089, HQ289, BS1162, NS2169] - On soil on rocks in Pinus tabulaeformis forest and Picea crassifolia + Populus davidiana forest.

B. buchananii (Hook.) Jaeg. [2500 m/HL2044] - On rotten logs and rocks in Picea crassifolia forest.

* B. kuroishicum Besch. [2300-3400 m/SY140, SG129] - On soil on rocks in the valley with transient creek.

B. plumosum (Hedw.) B.S.G. [2400-3100 m/SY024, SY129, HQ272, SG92-93, NS2151] - On rocks in Picea crassifolia forest.

B. salebrosum (Web. \& Mohr) B.S.G. [2300-2900 m/ SY129, HQ278, RJ366, BS1297] - On soil in Picea crassifolia forest.

Bryoerythrophyllum brachystegium (Besch.) Saito [2200-2500 m/SY126, HL2027]-On calcareous soil on rocks in Pinus tabulaeformis forest, Picea crassifolia forest, Populus davidiana forest and Ulmus glaucescens forest.

B. gymnostomum (Broth.) Chen (= B. ferruginascens (Stirt.) Giac.) [1900-2100 m/HQ295, RJ366, NS2179, NS2178] - On calcareous soil layer on rocks.

* B. inaequalifolium (Tayl.) Zand. [2450 m/HL2023] - On calcareous soil.

B. recurvirostrum (Hedw.) Chen [1900-3100 m/SY007, SY019, SY043, XK251, HQ272-273, HQ278, RJ338, SG93, HL1886, BS1197, HL1996, NS2192] - On calcareous soil on rocks, on soil in Pinus tabulaeformis forest, on creek bank in Pinus tabulaeformis + Picea crassifolia + Populus davidiana $+U l-$ mus glaucescens forest.

Bryum algovicum Sendt. ex C.Müll. [1800 m/BS1144] - On calcareous soil at creek bank, on relatively dry cliffs in shady canyons.

B. alpinum Huds. ex With. [1800-2300 m/SY131, NS2175, NS2180]-On soil in relatively mesic places along stream.

B. $\operatorname{arcticum}($ R.Brown.) B.S.G. [2900 m/BS1294] - On soil in various habitats.

B. argenteum Hedw. [1600-2500 m/SY002, SY008, XK257, RJ300-304, BS1176, HL2023, NS2137] One of the most widespread species in the area, tolerating heavy trampling and occurring everywhere, e.g. on soil among rocks on slopes, on rocks in Pinus tabulaeformis forest and Picea crassifolia forest.
* B. bicolor Dicks. (= B. dichotomum Hedw.) [2100$2300 \mathrm{~m} / \mathrm{SY} 048, \mathrm{SY} 069, \mathrm{SY} 166]$ - On soil in rocks crevice in Pinus tabulaeformis forest; at trunk bases in Ulmus glaucescens forest.

B. caespiticium Hedw. [2000-3400 m/SY001, SY007, XK199, HQ275-276, BS1184, HL1885, HL2010, NS2109] - Rather common in various habitats.

B. capillare Hedw. [2300-2600 m/SY175, HL2050] On arenaceous soil in Picea crassifolia forest, on rocks in canyon in Pinus tabulaeformis + Picea crassifolia forest.

B. cirrhatum Hoppe et Hornsch. (= B. lonchocaulon C.Müll.) [2000-2400 m/SY003, SY177-178, HQ276, NS2144, NS1350] - On soil in Picea crassifolia+ Pinus tabulaeformis forest.

** B. elegans Nees ex Brid. [3000 m/SG82] - On soil in alpine meadows.

B. pallens Swartz [2400-3300 m/HL1360, HL2050, HL1993] - On humus in Picea crassifolia forest and in alpine meadows.

* B. pallescens Schleich. ex Schwägr. [2300 m/ HL1912] - On soil among grasses on wet meadows.

* B. pseudotriquetrum (Hedw.) Gaertn. et al. [2500 m/HL1918] - On rock outcrops along creeks, streams.

B. rutilans Brid. [1800-2400 m/BS1144, HL1360] On wet soil at creek side.

* B. thomsonii Mitt. [2100-2300 m/SY126] - On soil on rock faces; on soil in forest of Pinus tabulaeformis, Picea crassifolia, Populus davidiana and Ulmus glaucescens.

B. turbinatum (Hedw.) Turn. [2100-2300 m/HL1899, HL2073] - On rock outcrops along creeks.

B. uliginosum (Brid.) B.S.G. [2100-3200 m/SY010, SY161, HQ276, BS1245, HL1900, HL1981] - On soil in various habitats.

Campylium hispidulum (Brid.) Mitt. [2000-2700 m/ SY003, SY025, HQ272-273, BS1185, NS1220] On rocks and at trunk bases in Picea crassifolia forest.

C. hispidulum (Brid.) Mitt. var. sommerfeltii (Myr.) Lindb. [2200-2500 m/BS1275, NS2092] - On soil on slopes and at trunk bases in Picea crassifolia forest and mixed forest.

C. stellatum (Hedw.) C.Jens. [2400-2900 m/BS1205, HL1352, HL2028, NS2114] - On humus in Picea crassifolia forest.

Cirriphyllum cirrhosum (Schwägr.) Grout [2500-2700 m/SY382, HL1949] - On soil in Picea crassifolia forest. 
C. piliferum (Hedw.) Grout [2000-2700 m/SY001, HQ286, BS1227, HL1322, HL1889, NS2098, HL2114] - On soil in Picea crassifolia + Populus davidiana mixed forests.

* Coscinodon cribrosus (Hedw.) Spruce [2250 m/SY4345, SY4347] - On soil-covered rocks on open place.

Cratoneuron filicinum (Hedw.) Spruce [1700-2700 m/ SY049, XK200, BS1252, HL1347, HL2050] - On rock on bank of permanent brook in Picea crassifolia forest and Pinus tabulaeformis forest.

C. longicostatum X.L. Bai [2700 m/BS1249] - On soil on xeric slopes.

* Crossidium crassinerve (De Not.) Jur. (as C. chloronotos, Flora Bryophyt. Intramongol.) [1800-2200 m/ SY102-103, XK208, XK241-242] - On soil on rock faces.

C. squamiferum (Viv.) Jur. [2000-2200 m/SY112-113, RJ364, HL1860, NS2124] - On soil on slopes under the shrubs.

Didymodon asperifolius (Mitt.) Crum [2300-3200 m/ SY024, SY096, SY189, RJ317, BS1143, HL1865, HL1986, NS2193] - On calcareous soil on rocks within shrubs community and forest.

D. fallax (Hedw.) Zand. [2200 m/HL1888] - On calcareous soil on rocks.

D. ferrugineus (Schimp. ex Besch.) Hill ( $=D$. rigidicaulis (C.Müll.) Saito) [2400-3400 m/SY025, SY123-124, XK191, XK241-242, RJ320, SG131, NS2183] - On calcareous soil on rocks.

D. giganteus (Funck) Jur. [3100 m/HL2002, HL2007] - On calcareous soil on rocks in alpine zone, often found on higher mountains above $3000 \mathrm{~m}$ alt.

D. johansenii (Williams) Crum [2200-3300 m/SY098, SG102, HL1948, HL1312, NS2163] - On calcareous soil in alpine meadows.

D. michiganensis (Steere) Saito [1950 m/NS2178] On thin soil on rock faces.

D. nigrescens (Mitt.) Saito [2000-3000 m/SY004, SY006, SY016-017, SY102-103, SY154-156, RJ317, HL1854] - On calcareous soil on rocks under shrubs.

D. perobtusus Broth. [3000-3400 m/SG104-105, SG126, HL1948, HL1988] - On calcareous soil on cliffs; in alpine meadows.

D. rigidulus Hedw. [2200-3250 m/SY045, SY096, SY179, RJ320, NS2121, HL1994] - On calcareous soil on rocky slopes in shrub community and forest.

D. rigidulus var. ditrichoides (Broth.) Zand. [2300-3000 $\mathrm{m} / \mathrm{SY} 71, \mathrm{HL} 1950, \mathrm{NS} 2088$ ] - On calcareous soil on rocks.
D. rigidulus var. flexicuspis (Broth.) comb. nov. - Barbula flexicuspis Broth. Hedwigia 80: 203. 1941. [1900-2200 m/SY059, SY073, SY148, NS2190] On calcareous soil on rock faces; on soil in Pinus tabulaeformis forest.

D. rigidulus var. gracils (Schleich. ex Hook. \& Grev.) Zand. [2700-2900 m/NS2107, SY12-13] - On calcareous soil on rocky slopes.

D. rigidulus var. icmadophilus (Schimp. ex C.Müll.) Zand. [1900-2200 m/SY023, SY163, XK247, NS2183, HL1310] - On soil in Picea crassifolia forest and Pinus tabulaeformis forest.

D. rufidulus (C.Müll.) Broth. [2400-3000 m/SG84, SG85, SG128, HL1975, HL1315] - On calcareous soil on alpine zone, occasionally on trunks in various forest.

D. tophaceus (Bird.) Lisa [1900-2300 m/SY056-068, SY154-155, HL1848, NS2160] - On soil on rocks along shaded creeks in forests.

D. vinealis (Bird.) Zand. [1500-3400 m/SY001, SY021-022, XK203-204, HQ261, RJ367-368, RJ371-372, SG78-79, HL1840, NS2126, HL1309] - One of the most widespread species in the area, tolerating heavy trampling and occurring everywhere.

Distichium capillaceum (Hedw.) B.S.G. [1900-3400 m/ SY030-031, SY180-181, HQ277, SG82-83, SG133, BS1170, NS2091, HL1870, SY57] - It is one of the dominant species on soil in forests of Pinus tabulaeformis, Picea crassifolia, and Picea crassifolia + Populus davidiana.

D. inclinatum (Hedw.) B.S.G. [2500-3000 m/SG99, BS1251, SY17] - On soil in Picea crassifolia forest, on soil in shrubs on alpine meadows.

Ditrichum flexicaule (Schwägr.) Hampe (= D. crispatissimum (C.Müll.) Par.) [2100-3400 m/SY030, SY085, SY378, SG115, SG119-123, BS1229, NS2103] - Relatively common and abundant in $P i$ cea crassifolia forest where it often forms pure population on the ground layer.

* D. pallidum (Hedw.) Hampe [2500 m/BS1230] - On soil in Picea crassifolia forest.

D. pusillum (Hedw.) Hamp. [2200 m/SY088] - On soil on rock faces in Pinus tabulaeformis forest.

Drummondia sinensis C.Müll. [1800-2500 m/HL2045, NS2187] - On soil on rocks, at trunk bases of Picea crassifolia in Picea crassifolia forest.

Encalypta alpina $\mathrm{Sm}$. [2000-3400 m/SY026, SY124, RJ368, SG83, SG86, NS2147, HL2025, BS2019, SY54] - On soil in Pinus tabulaeformis forest, $P i$ cea crassifolia forest and Populus davidiana forest; on rocks in alpine meadow. 
E. rhabdocarpa Schwägr. [2000-3400 m/SY131, SY135, SY149, HL1989, NS2111, BS1158] - Often found on soil in forests.

* E. spathulata C.Müll. [2000-2800 m/SY021, RJ364365, RJ372] - On rocks in Pinus tabulaeformis forest; on thin soil on the peak.

* E. tibetana Mitt. [2000-2500 m/SY078, SY172] On rock faces in forests of Pinus tabulaeformis, Picea crassifolia, Populus davidiana and Ulmus glaucescens; on wet soil in creek valleys.

E. vulgaris Hedw. [2000-3000 m/SY003, XK215-216, SG86, NS2136, HL1837] - On rock faces in Pinus tabulaeformis forest and Ulmus glaucescens forest; on rock outcrops in alpine meadows; on wet soil in creek valleys.

Entodon caliginosus (Mitt.) Jaeg. [2400-2900 m/ BS1260, NS2116, HL2035] - Often forms almost pure populations on soil and occurs as part of moss ground cover in Picea crassifolia forest .

E. concinnus (De Not.) Par. [2300-2900 m/HQ266, SY375, BS1218, HL1887, NS2102] - It is one of the dominant species forming the moss cover in $\mathrm{Pi}$ cea crassifolia forest.

Eurohypnum leptothallum (C.Müll.) Ando [2200-3200 m/SY065, HQ279, RJ331, RJ360, SG118, SG124, BS1141, NS2182] - On soil near rocks and on bare rocks on alpine meadows.

* E. leptothallum (C.Müll.) Ando var. tereticaule (C.Müll.) Gao \& Chang [2600-3400 m/HQ287, SG133] - On soil in Picea crassifolia forest, in alpine meadows.

Fabronia ciliaris (Brid.) Brid. [1900-2600 m/SY034, SY120, SY130, SY143, XK230, XK241, BS1212, HL2086, NS2159] - On trunks in forest and shrubs.

F. matsumurae Besch. [2200-2300 m/SY121, XK235] - On trunks of Ulmus glaucescens along roads, occasionally also on soil.

Fissidens bryoides Hedw. [1600m-2500 m/SY017, XK249-251, HQ269, RJ304, NS2145, HL1850, SY73] - On dank soil.

* Funaria discelioides C.Müll. [2200 m/SY145] - On soil in Ulmus glaucescens forest on sunny slopes.

F. hygrometrica Hedw. [2200 m/SY107] - On soil on rocks on open slopes and among open shrubs.

F. muhlenbergii Turn. in Schwägr. [1900-2300 m/ SY149-150, NS2177] - One of the most common species in xeric areas.

Grimmia anodon B.S.G. [3100 m/HL1962, NS2115] - On calcareous soil on rocks in alpine areas above $3000 \mathrm{~m}$ alt.
G. laevigata (Brid.) Brid. [2100-3000 m/SY015, SY094, XK248, RJ336-337, BS1189, HL1853, HL1950, NS2087] - Relatively common and abundant on rock faces in high mountain where it often forms pure population.

G. ovalis (Hedw.) Lindb. [2000-3200 m/SY005, XK210, HQ260, RJ370, SG105, HL1309, HL1966] - On calcareous soil on rocks; on rather dry rocks in mountain area.

G. pilifera P.Beauv. [3300 m/HL2006] - On soil on rocks in higher mountain above $3000 \mathrm{~m}$ alt.

G. subanodon Ochyra [3000 m/HL1954] - On calcareous soil on rocks and rock-fields at higher elevations.

* G. tergestina Tomm. ex B.S.G. [2000 m/SY162] On calcareous soil on rocks, on dry cliffs and rocks on open slopes and in rather dry canyons.

G. unicolor Hook. in Grev. [3200 m/HL1972] - On calcareous soil on rocks in alpine zone above $3000 \mathrm{~m}$ alt.

Gymnostomum aeruginosum Sm. [2000-2200 m/ SY083, HL1909, NS2118] - On soil on rock faces in Pinus tabulaeformis forest and Sabina chinensis forest.

G. calcareum Nees \& Hornsch. [2000-3400 m/SY016, SY086, SY188, XK207, SG105, HL1862, NS2167, BS1138, NS2140] - On soil on old wall and rock faces in Pinus tabulaeformis forest, Ulmus glaucescens forest and Picea crassifolia forest.

Hilpertia velenovskyi (Schiffn.) Zand. (= Tortula velenovskii Schiffn.) [1600-2100 m/SY185-186, BS1175, NS2125, HL1836] - On old loessial wall.

Homalothecium sericeum (Hedw.) B.S.G. [2100-3100 m/SY058, HQ295, SG107, BS1214, NS2146] - On soil in Picea crassifolia forest, on rotten logs, on soil in rocks crevices.

*Hymenostylium recurvirostrum (Hedw.) Dix. (= Gymnostomum recurvirostrum Hedw.) [2100-3400 m/ SY041, SY049, SG114, HL2059] - On rather wet rock faces along creeks in Pinus tabulaeformis forest and in alpine meadows.

H. recuvirostrum var. cylindricum (Bartr.) Zand. (= Gymnostomum aurantiacum (Mitt.) Jaeg.) [2000$2200 \mathrm{~m} / \mathrm{SY} 148$, HL1938] - On soil on shady rock faces in Pinus tabulaeformis forest, Picea crassifolia forest, Populus davidiana forest and Ulmus glaucescens forest.

H. recuvirostrum var. insigne (Dix.) Bartr. (= Gymnostomum subrigidulum (Broth.) Chen.) [2400 m/ BS2019] - On calcareous soil on rock faces.

** Hypnum bambergeri Schimp. [2500-3300 m/SY380, SG113] - On soil in Picea crassifolia forest and alpine meadows. 
H. cupressiforme Hedw. [2000-3200 m/SY003, SY004, HQ289, RJ335, HQ385, SG85-86, BS1169, HL1310, HL1843, NS2093] - Relatively common, found in various habitats in Helanshan.

H. cupressiforme Hedw. var. lacunosum Brid. [26003400 m/HQ273, SG129, NS2101, HL1966] - On dry soil in Picea crassifolia forest; on rocks in alpine meadows.

H.fertile Sendt. [2600 m/BS1282] - On soil on slopes with numerous rock outcrops in Picea crassifolia forest.

* H. hamulosum B.S.G. [2000-3400 m/SY016, SY023, SY127, SG131] - On soil in the valley with transient creek; on bare soil in alpine meadows.

H. lindbergii Mitt. (= Calliergoniella lindbergii (Mitt.) Hedenдs ) [2300-3200 m/SG107, BS1262] - On wet rocks in Picea crassifolia forest and in alpine meadows.

H. pallescens (Hedw.) P. Beauv. [2200-2800 m/SY079, BS1179] - On trunks in Picea crassifolia forest, on soil in Pinus tabulaeformis forest.

H. revolutum (Mitt.) Lindb. [2400-3200 m/BS1236, HL1358, HL2003, HL2033] - On rather dry soil on slopes, in Picea crassifolia forest, alpine meadows.

H. vaucheri Lesq. [1800-3200 m/SY003, RJ330, RJ352-353, RJ367, SY383, SG100, BS1155, HL1856, NS2088] - On soil in Pinus tabulaeformis + Picea crassifolia forest and alpine meadows.

H. vaucheri f. gracile Ando [2300-2500 m/BS1213, HL1303] - At trunk bases of Picea crassifolia; on rocks in Picea crassifolia forest.

H. vaucheri f. tereticaulis Ando [3000-3200 m/HL1318, HL1979] - On soil in shrubs on alpine meadows.

Indusiella thianschanica Broth. \& C.Müll. [1700-2100 $\mathrm{m} / \mathrm{BS} 1137$, HL1855] - On soil among dry rocks in mountain, as well as in rocky areas in deserts .

* Isopterygiopsis pulchella (Hedw.) Iwats. [2300-2400 $\mathrm{m} / \mathrm{SY} 088, \mathrm{SY} 175]$ - On soil in canyon beside creek in Pinus tabulaeformis + Picea crassifolia + Populus davidiana and Ulmus glaucescens forest.

Jaffueliobryum wrightii (Sull.) Thér. [2100-2800 m/ RJ329, RJ359, HL1859, HL2085] - Cliff crevices in alpine zone.

Leskeella nervosa (Brid.) Loeske [2700-3100 m/ HL1924, HL1978] - On rock outcrops in Picea crassifolia forest.

Leucodon sciuroides (Hedw.) Schwägr. [2400-3000 m/ HL1317, HL1936, NS2089] - On trunk bases of $P i$ cea crassifolia and shrubs, also on rock in forest.

Lindbergia brachyptera (Mitt.) Kindb. [1900 m/ NS2188] - On rocks in shrubby community and $P i$ nus tabulaeformis forest.
* L. sinensis (C.Müll.) Broth. [3200 m/HL1976] - On rather dry rocks in alpine meadows.

** Microbryum starckeanum (Hedw.) Zand. (= Pottia starckeana (Hedw.) C.Müll.) [2300 m/SY029, RJ340] - On soil in Pinus tabulaeformis + Junpierus rigida forest.

* Mielichhoferia mielichhoferiana (Funck ex Hook.) Loeske [2250 m/SY4346, SY4349] - On cliffs and rather dry rocks on steep slope in high elevation.

* Mnium heterophyllum (Hook.) Schwägr. [2300-3200 m/SY141, HQ291, SG107] - On soil and on rock faces in Picea crassifolia forest.

* M. laevinerve Card. [2300-3200 m/SY138, SG103] - On soil on rock faces in mixed forest of Pinus tabulaeformis + Picea crassifolia + Populus davidiana and Ulmus glaucescens.

M. lycopodioides Schwägr. [2300-2800 m/BS1267, HL1881, NS2152] - On soil in Picea crassifolia forest and shrubs, alpine meadows.

M. marginatum (Dicks ex With.) P.Beauv. [2000-3200 m/SY081, SY170, HQ384, SG107, BS1198, HL1882, NS2102] - On soil and rocks in Pinus tabulaeformis forest, shrubs and alpine meadows.

M. spinosum (Voit.) Schwägr. [1700-2500 m/SY181, HQ274, BS1236, HL1844, NS2113] - On soil under forest and shrubs.

M. thomsonii Schimp. (= M. orthorrhynchum Brid.) [2400-3100 m/SG99, HL1346, HL1959, HL2041] - On soil in Picea crassifolia forest, alpine meadows.

Molendoa schliephackei (Limpr.) Zand. (= Pleuroweisia schliephackei Limpr. ) [2000 m/XK244, HL1926] - On cliffs, soil on rock faces and in cliff crevices.

M. sendtneriana (B.S.G.) Limpr. [2000-2150 m/SY001, XK255-256, HL1897, NS2185] - Habitat similar to the previous species.

M. sendtneriana var. yunnanensis Gyoerf. (= Didymodon japonicus (Broth.) Saito) [1900 m/NS1163] On soil on rock faces.

Myurella julacea (Schwägr.) B.S.G. [2700-3200 m/ BS1235, HL1989] - On rock outcrops in Picea crassifolia forest, alpine meadows.

M. sibirica (C.Müll.) Reim. [3400 m/HL2012] - On rock faces in alpine meadows.

M. tenerrima (Brid.) Lindb. [2000-3200 m/SY053, SY088, SG112-113, HL2010] - On soil in Pinus tabulaeformis forest, alpine meadows.

* Okamuraea brachydictyon (Card.) Nog. [2900 m/ NS2100] - On rocks in Picea crassifolia forest. 
Orthotrichum affine Schrad. ex Brid. [2500-3500 m/ HQ278, HL2004] - On Picea crassifolia trunks; on rotten logs in alpine meadows; on rock faces.

O. anomalum Hedw. [2300-3000 m/SY144, HQ278, BS1220, HL1310, HL1948] - Habitats as in previous species.

O. obtusifolium Brid. [2300-2600 m/SY084, HQ267, BS1201, HL1945, NS2095] - On trunk of Picea crassifolia and Ulmus glaucescens.

* O. sordidum Sull. \& Lesq. in Aust. [2300-2800 m/ SY120-121, HQ279, RJ347] - On rotten logs of Picea crassifolia.

O. speciosum Nees in Sturm [2400-3400 m/HL2012, NS2095] - On Picea crassifolia trunks in Picea crassifolia forest, and occasionally also on soil.

* O. striatum Hedw. [2500-3100 m/HQ278, RJ345, SG97] - On fallen logs in Picea crassifolia forest.

Plagiomnium confertidens (Lindb. \& H. Arn.) T. Kop. [2350 m/HL1941] - On soil on rocks in Picea crassifolia forest.

P. ellipticum (Brid.) T.Kop. [2500 m/HL1357] - On wet soil along permanent creeks.

P. maximoviczii (Lindb.) T. Kop. [2400 m/HL1913] On soil in Picea crassifolia forest on steep slopes.

P. rostratum (Schrad.) T. Kop. [1900-2400 m/HL1904, NS2192] - On soil among grasses in Picea crassifolia forest.

* P. vesicatum (Besch.) T. Kop. [1900-2300 m/HL2070, NS2192] - On soil in tussock in Picea crassifolia forest.

* Podperaea krylovii (Podp.) Iwats. \& Glime [1900 m/ HQ269] - On soil at rock bases in Pinus tabulaeformis + Picea crassifolia + Populus davidiana and Junpierus rigida forest.

Pogonatum alpinum (Hedw.) Röhl. (= Polytrichastrum alpinum (Hedw.) G.L.Smith ) [3000 m/HL1990] On soil under shrubs; in alpine meadows.

Pohlia cruda (Hedw.) Lindb. [2800 m/NS2111] - On humus in Picea crassifolia forest.

Pottia intermedia (Turn.) Fuernr. (= Tortula modica Zand.) [2100 m/NS2143] - On soil on rock faces.

P. lanceolata (Hedw.) C.Müll. (= Tortula lanceola Zand.) [1900-2200 m/BS1178, NS2160] - On soil on rocks.

*P. truncata (Hedw.) B.S.G. [2600-2900 m/RJ03340] - On soil in Picea crassifolia forest.

Pseudoleskeella catenulata (Schrad.) Kindb. [24003400 m/HL1330, HL1924, HL2008] - On soil in Picea crassifolia forest, in shrub community, and in alpine zone.
P. tectorum (Brid.) Kindb. [3200 m/HL1987] - On rocks in alpine meadows.

Pseudostereodon procerrimus ( Mol.) Fleisch. in Broth. [1900-3400 m/SY031, HQ276, HQ386, SG132, BS1186, HL1308, HL1902, NS2099] - On soil in Pinus tabulaeformis + Picea crassifolia and Ulmus glaucescens forest.

Pterygoneurum ovatum (Hedw.) Dix. [2300-2500 m/ XK243, HL1844, HL2027] - On mesic soil on shady slopes.

P. subsessile (Brid.) Jur. [1500-2600 m/SY008, SY111112, XK195, XK240, RJ300-301, RJ311, HL2023, NS2124, NS2189] - On damp soil in Pinus tabulaeformis forest and Picea crassifolia forest; occasionally also on trunks.

Ptilium crista-castrensis (Hedw.) De Not. [2500 m/ HL1339] - On soil in Picea crassifolia forest.

* Pylaisiella polyantha (Hedw.) Grout [2800 m/HQ267] - On trunk of Picea crassifolia, on ground in Picea crassifolia forest.

* Rhizomnium punctatum (Hedw.) T.Kop. [1900-2200 $\mathrm{m} / \mathrm{XK} 237$, XK249-251] - On soil among rocks in canyon beside creeks.

Rhytidium rugosum (Hedw.) Kindb. [2600 m/HL1363] - On soil in Picea crassifolia forest.

Sanionia uncinata (Hedw.) Loeske (= Drepanocladus uncinatus (Hedw.) Warnst.) [2500-3000 m/BS1203, HL1332, HL2048] - On soil in Picea crassifolia forest; in shrub community, and in alpine zone.

Schistidium apocarpum (Hedw.) B.S.G. [2500-3400 m/ HL1313, HL1879, HL1983, NS2097, NS2117] - It is the dominant species on rocks in alpine zone.

S. strictum (Turn.) Loeske ex O.Maort. [2500-3300 m/ SG122, HL1312, HL2039, HL1952, NS1359] - Relatively common and abundant on rock faces in high mountain where it often forms pure population.

Stegonia latifolia (Schwägr.) Vent. ex Broth. [22003400 m/SY097, SY114, RJ315, SG95, HL1306, HL2016, NS2110] - On soil in meadows in alpine zone, and occasionally also in Pinus tabulaeformis + Picea crassifolia forest.

Syntrichia bidentata (X.-L.Bai) X.-L.Bai (= Tortula bidentata X.-L.Bai) [2800 m/RJ357] - On soil at the edge of Picea crassifolia forest.

S. caninervis Mitt. (= Tortula caninervis (Mitt.) Broth.) [2300-2800 m/RJ336, HL2076] - In rock crevices at mountain top, and in cliff crevices under overhangs.

S. laevipila Bird. [1800-2300 m/SY046, RJ318, BS1152, NS2168] - On soil in Pinus tabulaeformis + Picea crassifolia + Populus davidiana and Ulmus glaucescens forest. 
S. pagorum (Milde) Amann (= Tortula pagorum (Milde) De Not.) [2200-2500 m/SY066, SY151, HQ281, BS1212, BS1152, HL2030] - On soil among rocks and on trunks of trees

S. princeps (De Not.) Mitt. (= Tortula princeps De Not.) [2300-3400 m/RJ308-309, RJ313, RJ350-352, SG119-121, HL1961] - On soil under Picea crassifolia forest and shrub community.

S. ruralis (Hedw.) Web. \& Mohr (= Tortula ruralis (Hedw.) Gaertn. et al.) [2500-3100 m/BS1236, HL1304] - Same habitats as in previous species.

S. sinensis (C.Müll.) Ochyra (= Tortula sinensis (C.Müll.) Broth. in Levier) [2000-2500 m/SY037, SY143, XK253, BS1168, HL1876, NS2171]-Rare, on soil on rock faces.

Tayloria rudimenta X.-L.Bai \& B.C.Tan $[2050 \mathrm{~m} /$ SY099] - Rare, on humus within forest in swampy area where light can hardly shine in. Second known locality in China.

Thuidium philibertii Limpr. [2700 m/BS1253, HL1356] - On soil in Picea crassifolia forest where it often forms almost pure populations on the ground layer.

Timmia bavarica Hessl. (= T. megapolitana ssp. bavarica (Hessl.) Brid.) [2200-3400 m/SY010, SY140141, XK252, HQ296, SY379, SG129-130, BS1180, HL1334, HL1890, NS2151] - Relatively abundant and common species in Pinus tabulaeformis forest and Picea crassifolia + Populus davidiana forest where it is often codominates in forming the moss cover on soil.

T. megapolitana Hedw. [2500-2600 m/HQ288, HL1360] - On soil on slopes with numerous rock outcrops in Picea crassifolia forest.

Timmiella anomala (B.S.G.) Limpr. [1700-2000 m/ XK196, XK213, XK246, NS2172, NS2173] - On calcareous soil in cliff crevices.

Tortella fragilis (Hook. \& Wils.) Limpr. [2000-3400 m/SY051, SY077, XK242, SG122-123, BS1221, HL1880] - On calcareous soil on open slopes, in alpine meadows, on soil in canyon in Pinus tabulaeformis + Picea crassifolia + Populus davidiana and Ulmus glaucescens forest.

T. tortuosa (Hedw.) Limpr. [2200-3200 m/HL1889, HL1984] - On calcareous soil on rocks, and in alpine meadows.

Tortula atrovirens $(\mathrm{Sm}$.$) Lindb. (=$ Desmatodon convolutus (Brid.) Grout) [1700-2400 m/SY008, XK259, RJ300-301, BS1181, HL2077, NS2176] On soil on rocks in Pinus tabulaeformis forest and shrubs, in canyon beside creeks.
T. leucostoma (R. Br.) Hook. \& Grev. (= Desmatodon suberectus (Hook.) Limpr.) [3100 m/HL1306] - On soil on slopes with numerous rock outcrops.

T. mucronifolia Schwägr. [2000-3200 m/SY017, SY164, SY169, SY171, HQ262, HQ278, RJ362, SG94, BS1197, NS2139, HL1878] - On soil on rock faces.

T. systylia (Schimp.) Lindb. (= Desmatodon systylius Schimp.) [3200 m/HL1306] - On soil near a base of shrubs in alpine zone.

T. yunnanensis Chen [2500-3300 m/RJ320, SG127, HL1959] - On soil; in shrubby community; on slopes; in alpine meadows.

Trachycystis ussuriensis (Maack \& Regel) T.Kop. [2400-2900 m/HQ291, SY376, BS1284] - On soil in Picea crassifolia forest.

* Trichostomum crispulum Bruch in F.A.Müll. [2000$2300 \mathrm{~m} / \mathrm{SY} 005$, SY172, SY175] - On rock faces in shady creek in Pinus tabulaeformis + Picea crassifolia + Populus davidiana and Ulmus glaucescens forest.

T. planifolium (Dix.) Zand. [2400 m/HL2023] - On soil on rocks.

Voitia nivalis Hornsch. [2100-3200 m/SY082, SY091092, SG110, BS1288, HL2015, NS2130] - On humus in Picea crassifolia forest and alpine meadows.

* Warnstorfia fluitans (Hedw.) Loeske (= Drepanocladus fluitans (Hedw.) Warnst.) [1800 m/BS1142] On rocks in stream in springy area.

* Weissia controversa Hedw. [2000 m/XK206, XK214] - On soil under rocks on sunny slopes.

* W. edentula Mitt. [2100-2300 m/SY052, SY118] On soil under rocks in shady creek in Pinus tabulaeformis + Picea crassifolia + Populus davidiana and Ulmus glaucescens forest.

* W. newcomeri (Bartr.) Saito [2000-2300 m/SY029, SY086, XK206, XK242] - On soil in rock crevices in Pinus tabulaeformis + Junpierus rigida forest.

W. semipallida C.Müll. [1500-2900 m/SY104, XK193, HL1945, NS2109] - On soil on rock faces on sunny slopes.

\section{ACKNOWLEDGEMENTS}

We appreciate the National Nature Science Foundation of China (no. 30360024) for support of the research. We wish to express our thanks to administration of Helan Mountain Nature Preserve who invited us for research of bryophytes and provided guides and vehicles. Also, we want to thank Prof. Benito C.Tan for careful reading of the whole text, valuable corrections and helpful discussion. 


\section{LiTERATURE CITED}

BAI, X.L. 1987. Preliminary report of the mosses in Inner Mongolia, China. - Acta Scientiarum Naturalium Universitatis Intramongolicae 18(2): 311-350.

BAI, X.L. 1993. The Bryoflora of Inner Mongolia. - Chenia 1: 83-98.

BAI, X.L. 1997. Flora Bryophytarum Intramongolicarum. Typis Universitatis Intramongolicae, 541 pp. (in Chinese).

BAI, X.L. 1998. Some bryophyte species new to China. Chenia 5: 31-34.

BAI, X.L., \& L.-F. HAO 1996. Some moss species new to China. - Acta Scientiarum Naturalium Universitatis Intramongolicae 27(3): 412-416 (in Chinese).

BAI, X.L. \& B.C. TAN 2000. Tayloria rudimenta (Musci, Splachnaceae). a new species from Ningxia Huizu Auronomous Region of China. - Cryptogamie, Bryol. 21(1):3-5.

BAI X.L \& B.C. TAN 2004. New distribution record of Coscinodon cribrosus (Hedw.) Spruce (Musci,Grimmiaceae) in china. - Arctoa 13:1-4.

BAI, X.L. \& P.C. WU 1997. A genus and two species of Pottiaceae new to China. - Acta Phytotaxonomica Sinica 35(1): $83-85$.

BAI, X.-L., L.M. ZHAO, W. SUN \& W.G. SUN 1998. A preliminary study on the species diversity, phytomass and ecological effect of bryophytes in Helan Mountain, China. Acta Scientiarum Naturalium Universitatis Intramongolicae 29(1): 118-124 (in Chinese).

DI, W.Z. 1986. Plantae vasculares Helanshanicae. - Northwestern University Press (in Chinese).
IGNATOV, M.S., H. ANDO \& E.A. IGNATOVA 1996. Bryophyte flora of Altai Mountains. VII. Hypnaceae and related pleurocarps with bi- or ecostate leaves. - Arctoa 6: 21-112.

LIANG, C. Z., Z.Y. ZHU, W. WANG \& H. PEI 2004. The diversity and spatial distribution of plant communities in Helan Mountain. - Acta Phytoecologica Sinica 28(3): 361368 (in Chinese)

LU, D.Z. 1998. The frequent bryophytes in the mountain Helanshan. - Journal of Beijing Forestry University 20(1): 36-41 (in Chinese).

SHI, Y.Z., Y. H. SHI, Z.F. BAI \& J.Z. SUN 1989. Geography of Inner Mongolia. - In: Huhhot, Typis Intramongolicae Populations: $32-33$ (in Chinese).

TIAN, L.S. 1996. The east slope vegetation of Helan Mountain. - Huhhot, Inner Mongolia University Press. (in Chinese).

TONG, Z.G. 1963. Notes on some xerophytic mosses in China. - Acta Scientiarum Naturalium Universitatis Intramongolicae 2: 73-85 (in Chinese).

XIE, X.M., W. L. MA \& L.C. ZHAO 1999. Ecogeographical distribution and floristic characteristics of Gramineae in Helan Moutain. - Journal of Arid Land Resources and Environment. 13(2): 17-24 (in Chinese).

WU, P. C., JIA, Y. \& WANG, M.Z. 2001. Phytogeographical relationships of the bryophytes between China and North America. - Acta Phytotaxonomica Sinica 39(6): 526-539 (in Chinese).

WU Z.Y. (ed.) 1983. The vegetation of China. - Beijing, Science Press (in Chinese). 